\title{
O ressentimento do eleitor natalense nas eleições presidenciais de 2018
}

The resentment of electors from the Brazilian city of Natal in the 2018 presidential election

Lindijane Bento Almeida [I] Terezinha Albuquerque Barros [II] Jaylan Ferreira Macedo [III]

\section{Resumo}

0 ressentimento político impulsionou, nos últimos anos, a ascensão de lideranças e de movimentos com perfis de extrema-direita. No Brasil, esse cenário ganha outras proporções depois das eleições presidenciais de 2018. Diante disso, o presente trabalho tem como objetivo compreender o perfil do eleitor ressentido com a política brasileira na cidade do Natal/RN. Este artigo analisa os resultados do último pleito eleitoral, relacionando-os com alguns aspectos da realidade social, visando a compreender o voto à luz da teoria do ressentimento político. Optamos pelo uso do recurso de mapas para uma imersão espacial nesse fenômeno nos bairros, o que permitiu uma leitura das características gerais do eleitorado, indicando que o ressentimento não se localiza apenas nos lugares excluídos da cidade.

Palavras-chave: democracia; ressentimento político; eleições presidenciais; polarização; Natal/RN.

\begin{abstract}
Political resentment has driven the rise of leaders and movements with far-right profiles in recent years. In Brazil, this scenario worsened after the 2018 presidential election. In view of this context, the present work aims to understand the profile of voters who are resentful of Brazilian politics in the city of Natal, State of Rio Grande do Norte. The article analyzes the results of the last election, relating them to some aspects of social reality, in order to comprehend the votes in light of the theory of political resentment. We used maps for a spatial immersion in this phenomenon in the city's neighborhoods, which enabled us to read the general characteristics of the electorate, indicating that resentment is not located only in the excluded places of the city.
\end{abstract}

Keywords: democracy; political resentment; presidential election; polarization; Natal/State of Rio Grande do Norte. 


\section{Introdução}

Os últimos anos foram marcados pela ascensão de lideranças políticas e de movimentos sociais com um perfil político de extrema-direita, como evidencia o aumento da quantidade de votos arrecadados por partidos com esse mesmo direcionamento ideológico em diversos continentes, como na Europa, na América do Norte e, mais recentemente, na América do Sul; como vivenciou o Brasil nas últimas eleições presidenciais realizadas em 2018. Novos movimentos com um caráter xenófobo, anti-estabelishment e supremacista ganham corpo em países como Alemanha, França, Estados Unidos e Hungria. O populismo político (Zakaria, 1997; Weffort, 2003) reacende, e figuras como Viktor Orbán (Hungria), Donald Trump (Estados Unidos), Marine Le Pen (França) e Jair Bolsonaro (Brasil) passam a ser símbolos desse grupo de ressentidos e descontentes que veem de maneira desesperançosa o futuro do país e da própria democracia.

No Brasil, mais especificamente, movimentos com caráter reivindicatório da garantia dos direitos sociais dão espaço a manifestações contra a corrupção, fazendo-se consagrar a grande agenda eleitoral de 2018, o antipetismo, que se torna mais intenso depois do impeachment da então presidente, Dilma Rousseff, do Partido dos Trabalhadores (PT), ${ }^{1}$ que rompe com a trajetória de aprovação dos anos anteriores e dá início aos altos índices de desaprovação popular no período logo após a sua reeleição, em 2014. Assim como os avanços da operação de combate à corrupção, Lava-Jato ${ }^{2}$ que enfraqueceram diversos partidos políticos, principalmente o PT, oportunizando a ascensão do candidato Jair Bolsonaro (PSL). ${ }^{3}$
O "mito", como é chamado por seus apoiadores mais fiéis, introduz na política do País um discurso público totalmente distinto do que era visto nas últimas eleições presidenciais. Com manifestações pró-militarismo, pró-armamentista, ataque às minorias, anti-estabelishment, além de ser simpático aos valores moralmente cristãos (a favor da família, contra o aborto, contra a agenda da população LGBTQI+) e defensor de uma agenda de combate à corrupção, mesmo tendo em seu núcleo familiar e partidário pessoas envolvidas em casos de desvirtuação com o dinheiro público, Jair Bolsonaro torna-se um protagonista, principalmente quando oferece soluções fáceis para problemas complexos na sociedade brasileira.

Para entender melhor esse cenário, buscamos responder quais seriam os motivos que levaram esse perfil de candidato, com discursos públicos de glorificação a regimes autoritários, a ascender como liderança representativa, alicerçada com apoio popular, em uma democracia que parecia caminhar cada vez mais para sua consolidação, como no caso brasileiro. O que oportuniza o debate antigo na ciência política de que somente eleições livres e justas não são elementos suficientes para enquadrar regimes como democráticos ou não democráticos, contrariando Schumpeter (1942) e Przeworski (1999), cujas clássicas visões processuais de democracia referem-se a uma eleição competitiva com condições iguais de vitória. Przeworski (1999) ainda acredita na racionalidade dos eleitores, quando estes escolherem os seus representantes baseados em um projeto socialmente benéfico. Não desconsiderando a eleição como elemento essencial, mas apontando-a como não suficiente, existe uma série de autores (Dahl, 1996; Zakaria, 1997; Mainwaring, 
Brinks e Pérez-Linã, 2001; Castells, 2018) que amplia a visão de democracia quando reitera que a existência de uma categoria mínima de direitos sociais, políticos e civis é fundamental para classificar um regime democrático.

Até porque, discordando de Przeworski (1999), não só o ressentimento pode tornar as pessoas em pobres juízes de suas escolhas. Assim como nem sempre os líderes que são eleitos pelo voto popular irão alicerçar suas ações, respeitando as formas e as regras da democracia que o fizeram eleito; uma vez que discursos que enfraquecem publicamente as normas constitucionais e institucionais de seus países vêm fazendo parte desses governos, de forma que suas lideranças passam a ganhar mais poder de influência e representatividade política.

Mounk (2018) analisa, ainda, que o perfil dessas lideranças tem características similares: colocam-se como vendedores de fáceis soluções para os problemas e se apresentam como defensores de uma "limpeza" na política. De face populista, eles convencem aos que não querem admitir que o mundo real pode ser complicado e que, inebriando-se de ilusões, buscam alguém para culpar pelo suposto fracasso na resolução desses problemas.

Esse novo populismo que surge no século XXI adquire uma nova face do que já foi visto nas décadas anteriores em continentes como a América Latina: o surgimento de líderes que, mesmo não usando de sua simpatia, movimentam massas em defesa de medidas antidemocráticas. 0 que fortaleceu o elo com uma população ressentida em relação ao desempenho dos seus representantes. Esses novos líderes passam a se considerar como os fiéis representantes de uma "maioria" heterossexual, branca, cristã e conservadora. Assim, o pluralismo político passa, nesse novo cenário a ser contraposto, e os pilares liberais de garantia de direitos ficam em plano secundário na democracia iliberal, como denomina Zakaria (1997) e Mounk (2018).

Considerando esse contexto, o presente trabalho tem como objetivo compreender o perfil do eleitor ressentido com a política brasileira, destacando que, quando se trata do Brasil e de suas dimensões territoriais, a análise aqui proposta se torna complexa. Visando a explorar esse fenômeno político, optamos por imergir para o caso particular de uma capital do País, a escolhida foi a do Rio Grande do Norte, Natal, localizada na região Nordeste. Nessa região, a responsável por concentrar a maior parcela do eleitorado do PT no País, três capitais (Natal, João Pessoa e Maceió), nas últimas eleições, canalizaram a maioria dos seus votos para Jair Bolsonaro.

Como procedimento metodológico, o artigo analisa os resultados de votação das últimas eleições presidenciais de 2018 no município de Natal, relacionando-os com aspectos da realidade social local, visando a mapear e compreender o voto à luz da teoria do ressentimento político (Ferrão, 2019; Rodríguez-Pose, 2018). Para melhor apresentar os achados da pesquisa, optamos pelo recurso de mapas, pois ele permitiu uma imersão espacial do fenômeno político nos bairros da cidade. Os modelos selecionados foram os mapas de distribuição por superfície de tendência, os quais demonstraram a distribuição média dos votos dos candidatos Jair Bolsonaro, Fernando Haddad, além dos brancos/nulos na cidade, permitindo identificar as características gerais do eleitorado. 0 segundo modelo foi os coropléticos, que nos permitiu analisar a proporção de votos em cada bairro. A base de dados da pesquisa está ancorada no Tribunal Superior 
Eleitoral (TSE), e as dimensões socioeconômicas foram obtidas a partir dos repositórios da Prefeitura Municipal do Natal (PMN).

Como forma elucidativa, sentimos a necessidade de apresentar melhor o cenário escolhido para a nossa pesquisa. De acordo com o Instituto Brasileiro de Geografia e Estatística (IBGE, 2019), o município de Natal tem uma população de 884.122 mil habitantes, sendo a vigésima cidade mais populosa do País. Localizada no litoral nordestino, tem uma área total de $169.9 \mathrm{~km}^{2}$, possuindo $100 \%$ de sua população localizada em área urbana.

No que se refere à desigualdade social, podemos dizer que o Índice de Gini passou de 0,61, em 1991, para 0,62 em 2010. Nos últimos anos, o Índice de Desenvolvimento Humano Municipal (IDHM) de Natal cresceu $15 \%$, passando de 0,664, em 2000, para 0,763, em 2010 (IBGE, 2010). Natal caracteriza-se, do ponto de vista econômico, pela predominância do setor terciário, no qual o serviço público aparece como o grande empregador, sendo uma localidade na qual o setor médio é preponderante.

$\mathrm{O}$ artigo, a seguir, está estruturado em três seções. Na primeira seção, apresentamos ao leitor breves considerações sobre os estudos desenvolvidos acerca dos conceitos de democracia iliberal e da geografia do ressentimento, os quais buscam fazer uma reflexão do perfil dos novos líderes que surgem de maneira exponencial em diversos países. Na segunda seção, caracterizamos quem são os descontentes e ressentidos em Natal, à luz do contexto brasileiro, que passam a direcionar o seu voto e seu apoio a candidatos que oferecem soluções fáceis para problemas complexos. Por fim, na terceira e última seção, tecemos as considerações finais em relação às inferências da pesquisa.

\section{A geografia do ressentimento e a democracia iliberal}

Nos últimos anos, os partidos e lideranças tradicionais vêm sendo questionados, assim como o próprio regime democrático. A democracia liberal, antes respeitada e almejada por todos, passa a ser tratada de maneira hostil em países que, até então, tiveram uma trajetória de respeito às normas republicanas e ampla tradição democrática, como os Estados Unidos (Mounk, 2018).

A eleição de figuras que se colocam publicamente contra normas constitucionais que ditaram a formação das democracias liberais se mostra uma realidade intercontinental. Esses líderes passam a ganhar mais poder e influência, assim como maior representatividade política, e suas práticas e discursos conduzem a uma democracia iliberal, que nada mais é que uma democracia sem direitos ou, melhor dizendo, na qual o constitucionalismo liberal passa a ser questionado.

É importante compreender que a ideia de Mounk (ibid.) se assenta na visão de que a população de modo geral - ou os eleitores, de maneira mais específica - considera $(\mathrm{m})$ que os problemas presentes na sociedade podem ser de fácil elucidação; ganhando maior proeminência essas visões quando endossadas por candidatos populistas, já que as elas não seriam qualificadas pela população como um sinal de "senso comum", mas sim como um sinal de autenticidade do candidato que apresenta essas proposições.

A dificuldade de resolver os problemas que incomodam diariamente os votantes é vista como um fator de má vontade política e incapacidade de resposta dos governantes. 
O autor reforça essa sua argumentação quando analisa a eleição americana e as propostas de Donald Trump que, como exemplo, propõe resolver a agenda da imigração latino-americana com a construção de um muro na fronteira com o México. Isso nos remete à possibilidade de essa proposta ser vista como um sinal de que o plano apresentado pelo candidato é realmente a solução dos problemas.

Os eleitores não gostam de pensar que o mundo é complicado. Eles certamente não gostam de saber que não existe resposta imediata para seus problemas. Diante de políticos que parecem cada vez menos capazes de governar um mundo cada vez mais complexo, muitos estão cada vez mais dispostos a votar em quem promete uma solução simples. (Ibid., p. 38; tradução nossa)

O fenômeno do ressentimento político também passa a ser estudado em virtude da ascensão de lideranças com caráter antiliberal. Uma forma de compreender esse fenômeno é apontada a partir da ótica dos "lugares que importam e [d]os lugares que não importam". Rodríguez-Pose (2018) parte da premissa de que estratégias equivocadas de desenvolvimento adotadas no continente europeu teriam direcionado uma divisão de diversos países em duas classificações: aqueles prósperos e dinâmicos, do ponto de vista econômico, e os demais lugares excluídos, colocados em segundo plano, nos quais os residentes, a posteriori, buscariam novas oportunidades de emprego nos centros urbanos em ascensão.

Essa exclusão, do ponto de vista econômico, produziria uma onda de descontentamento e uma reação que resultaria no que é denominado, por Rodríguez-Pose (2018, p. 190), The revenge of the places that don't matter ou, em tradução literal, a vingança dos lugares que não importam. Esse termo qualificaria as mudanças na perspectiva de uma parcela territorial do eleitorado que reagiria contra um conjunto de fatores de caráter negativo. Essas localidades passam a ser afetadas por baixas taxas de crescimento econômico, aumento do desemprego e da pobreza, além de uma incerteza sobre o presente e uma insegurança sobre qualquer perspectiva de futuro. Dessa forma, esses lugares excluídos passariam a direcionar o seu voto para lideranças que detêm um caráter mais populista e de perfil nacionalista, ligadas principalmente à extrema-direita do espectro político ideológico. As eleições seriam um modo de fazer eclodir esse ressentimento sobre o desabono territorial e, ao mesmo tempo, uma forma de expressar o ressentimento em relação aos fatores acima citados.

No caso da Europa, esses lugares seriam exemplificados principalmente pelas cidades que desempenhavam um papel industrial e que notaram, com o avanço da globalização, uma deterioração em sua qualidade de vida e a decadência das atividades econômicas anteriormente desempenhadas. 0 ressentimento surgiria não como uma reação pessoal de todas "as pessoas que não importam" - aquelas que se consideram excluídas socialmente -, mas sim como uma espécie de vingança do território como um todo, uma reação dos lugares que também estaria ligada a um sentimento nostálgico de que o passado era mais animador. A desigualdade social e de caráter interpessoal seria um fator importante, mas a ascensão desse perfil de liderança partiria de uma desigualdade territorial que foi negligenciada (ibid., 2018). Ainda de acordo com o autor: 
O populismo não se estabeleceu entre os mais pobres, mas sim em uma combinação de regiões pobres e áreas que sofreram longos períodos de declínio. Tem sido assim, portanto, "os lugares que não importam" e não "as pessoas que não importam" que reagiram. Nessas áreas tem sido, muito frequentemente, os relativamente abastados, aqueles em empregos bem remunerados ou aposentados que atendem ao chamado do populismo. (Ibid., p. 201; tradução nossa)

Para corroborar a argumentação, a análise do comportamento do eleitorado em dois grandes centros urbanos, a cidade de Paris e de Nova York, demonstrou que, em ambos, os mais pobres direcionam o voto para candidatos mais sistemáticos e com discurso mais distante do populismo. Em Nova York, ricos e pobres votaram em conjunto na candidata democrata Hillary Clinton contra o republicano Donald Trump. Em Paris, tal fator se repetiria com a candidatura de Emmanuel Macron, que disputou o segundo turno das eleições francesas com Marine Le Pen, candidata de extrema-direita. Desse modo, o ressentimento não seria uma reação oriunda desses centros urbanos, analisando o caso da Europa e dos Estados Unidos (ibid.).

Ferrão (2019), partindo para uma análise mais específica sobre os descontentes, oferece o seu aporte a partir de uma divisão bastante contributiva que qualifica esse fenômeno a partir dos aspectos geográficos, sociológicos, econômicos e culturais. Do ponto de vista geográfico, os "descontentes" poderiam ser qualificados como habitantes de cidades de porte pequeno e médio, que detinham, como também destacou Rodríguez-Pose (2018), um passado industrial e/ou alicerçado em áreas rurais. Da perspectiva sociológica, seriam grupos que estariam localizados nas classes médias e populares tradicionais (operários, assalariados do setor público e privado, camponeses, profissionais autônomos e desempregados), em situação de precariedade social, com baixos níveis de instrução e qualificação. Economicamente, seriam populações enfrentando situação de vulnerabilidade social, famílias com endividamentos e com baixa segurança socioeconômica. Por último, do ponto de vista cultural, seriam pessoas que sentem sua identidade e valores ameaçados pela agenda urbana advinda com a globalização que direciona o seu foco para as metrópoles cosmopolitas (Ferrão, 2019).

O efeito da globalização nessa mudança de direcionamento político, analisado em certos territórios, pode estar essencialmente na quebra das fronteiras territoriais que a interação entre as economias globais resultou e na consequente mudança de hábitos sociais e econômicos advindos dessa integração. A sensação de exclusão dos descontentes aprofunda-se ainda mais, e eles surgem como os "perdedores da globalização" (ibid., p. 62). Assim, passariam a defender a desglobalização, as políticas de caráter mais protecionista e xenofóbicas, alicerçadas em uma nova valorização de suas identidades morais, religiosas e culturais, muito imbuídas, como relembra Ferrão (ibid.), no great again, que foi uma das expressões utilizadas na campanha do então presidente americano, Donald Trump. Ainda segundo Ferrão (ibid., p. 63):

[...] não estamos perante uma guerra entre territórios, embora a geografia do voto nacionalista e xenófobo pareça apontar nesse sentido. Enfrentamos, sim, graves problemas de injustiça 
espacial e de falta de coesão territorial decorrentes dos processos de globalização, do poder das redes cosmopolitas desterritorializadas e do ideário do triunfalismo urbano.

Uma indagação que pode florescer é referente a quais outros fatores seriam utilizados para analisar a crise de representatividade enfrentada pela democracia liberal, que parecia tão consagrada nos continentes europeu e norte-americano e que avançou para a consolidação também no Brasil. Quem oferece esse aporte é Ferrão (ibid.), ao indicar seis tendências que ele considera transversais. Entre elas, poderíamos aqui citar a redução da participação eleitoral evidenciada com o aumento das taxas de abstenção; a retração eleitoral e o consequente enfraquecimento de partidos de centro-esquerda e centro-direita; a consolidação de candidatos e movimentos com caráter nacionalista e antissistema; a baixa influência de partidos com viés marxista; o aumento da fragmentação partidária; e um baixo interesse de jovens para a participação direta na política. Ainda segundo o autor:

Essas seis tendências relativas às práticas associadas aos sistemas de representação demoliberal refletem uma crescente desconfiança e um alheamento cada vez maior dos cidadãos em relação aos partidos políticos e aos sistemas de democracia representativa (Belchior, 2016), o que significa que a função "representativa" dos eleitos é cada vez menos efetiva. (Ibid., p. 58)

No cenário brasileiro, as tendências trazidas por Ferrão (ibid.) também podem ser vistas de maneira similar. A primeira dimensão, o crescimento das abstenções, mesmo que não tenha sido de maneira exponencial, mostra-se uma realidade no Brasil. Nas eleições presidenciais de 2010, eram 24 milhões de abstenções; nas de 2014, o número passa para 27 milhões; e, em 2018, sobe para 29 milhões; analisando apenas o primeiro turno eleitoral dos três pleitos. No segundo turno, o número de abstenções passa de 29 milhões, em 2010, para 30 milhões, em 2014, e, em 2018, esse número atinge os 31 milhões. Os dados evidenciam que, além do crescimento, as abstenções obtêm maiores valores nos segundos turnos das eleições, quando comparadas às dos primeiros turnos.

No que se refere a uma segunda dimensão apresentada por Ferrão (ibid.), na realidade brasileira, observamos que há um decréscimo na votação dos partidos que antes centralizavam o debate político, principalmente os de espectro político-ideológico de centro-esquerda e de centro-direita. Esse fato é evidenciado quando se observam, principalmente, os dados do Partido da Social-Democracia Brasileira (PSDB) - centro- direita - que saiu de uma votação na casa dos 30\%, nas eleições presidenciais de 2014 , para menos de $5 \%$ dos votos válidos no primeiro turno das eleições presidenciais de 2018. O Partido dos Trabalhadores (PT), partido de centro-esquerda, que teve $46,91 \%$ dos votos válidos no primeiro turno das eleições presidenciais em 2010, conquista apenas $29,28 \%$ dos votos na eleição presidencial de 2018. Ambos os partidos polarizavam as eleições presidenciais desde 1994. Já os partidos de orientação marxista, trotskista ou similares nunca tiveram votação expressiva nas eleições brasileiras. A maior votação foi em 2014, quando a candidata Luciana Genro, do Partido Socialismo e Liberdade (PSOL), atingiu $1,55 \%$ dos votos válidos, o que 
representou um pouco mais de 1,6 milhão de votos. O PSOL é um dos poucos partidos de orientação trotskista no País.

Ainda analisando as dimensões propostas pelo autor, no que diz respeito à fragmentação partidária, evidenciamos, no cenário brasileiro, a partir das eleições de 2010, que apenas 22 partidos tinham representação na Câmara Federal; em 2014, foram 28 partidos; e, em 2018, 30 partidos conseguiram representação eleitoral. 0 partido com maior bancada, o PT, tem aproximadamente $11 \%$ dos deputados que compõem a Câmara Federal. Sendo assim a maior fragmentação eleitoral da história desde a redemocratização do País. ${ }^{4}$

No que tange à dimensão de crescimento de movimentos e partidos mais à extrema-direita, no Brasil também constatamos, alinhada a esse crescimento, a ascensão de figuras mais ligadas ao conservadorismo e às igrejas evangélicas, como Marcos Feliciano, Jair Bolsonaro e outras lideranças que passam a figurar no debate eleitoral. Em 2016, um movimento mais ligado à direita do espectro político, o Movimento Brasil Livre (MBL), fortalece as manifestações que culminaram no impeachment da ex-presidente Dilma Rousseff (PT), o que demonstra a grave crise de representatividade enfrentada pelo Brasil a partir de 2013.

No segundo turno, uma pesquisa do Instituto Datafolha (Datafolha, 2018) divulgou dados acerca dos motivos do voto em Bolsonaro: $30 \%$ dos eleitores disseram que votariam nele por desejarem uma renovação na política ou para eleger alguém que nunca tivesse sido presidente; ao mesmo tempo, $25 \%$ afirmavam votar no candidato por rejeitar 0 PT, evidenciando um ressentimento em relação ao PT no Brasil.
No ano de 2013, diversas cidades brasileiras, principalmente as capitais, foram sede de grandes manifestações populares que se apresentaram de maneira inicial contra reajustes na tarifa do transporte público. Com a evolução das manifestações, a percepção é que o seu caráter foi ficando mais difuso, incluindo pautas que buscavam a melhoria nos serviços públicos e uma gestão pública livre da corrupção, que podemos sintetizar na ideia de que o cidadão brasileiro reivindicava ações a favor da democracia (Maricato et al., 2013; Rolnik, 2013; Vainer, 2013; Avritzer, 2016; Almeida et al., 2018). Em pronunciamento na rede nacional, a presidente à época, Dilma Rousseff (PT), apresentou um pacote de soluções que seria posto em prática para atender à demanda dos manifestantes que chegaram a realizar grandes protestos em frente ao Congresso Nacional. Até então mantendo uma alta aprovação de seu governo, Dilma Rousseff observava a sua aprovação cair para o menor índice desde que assumiu a presidência, em 2011.

As manifestações de rua passaram a ganhar um caráter suprapartidário a partir do momento em que a presença de militantes partidários ou de instrumentos de apologia a partidos políticos passa a ser rechaçada pelos manifestantes em diversas cidades brasileiras, culminando, por exemplo, na retirada das bandeiras de partidos e lideranças políticas. 0 PT, partido que sempre teve uma trajetória de contato com as classes mais populares, a partir de 2014, passa a ser alvo de duras críticas relacionadas à corrupção na esfera pública de governo em virtude das investigações da Operação Lava-Jato. Essa Operação tornou-se amplamente conhecida e divulgada na imprensa nacional e teve, como consequência, uma polarização no Brasil que criou a imagem do 
antipetismo, o qual tomamos como elemento-chave para analisar o ressentimento do eleitorado brasileiro.

\section{Democracia e eleições presidenciais no Brasil e em Natal}

A partir da Constituição Federal de 1988, a sociedade brasileira voltou a ter o direito de escolher seus próprios representantes, dando início à retomada da democracia representativa no País, a qual passou a contar com um cenário de multipartidarismo alicerçado em um sistema eleitoral pautado em regras constitucionais e republicanas.

Nas últimas décadas, a democracia representativa passa por um revés quando vivencia um momento de crise, principalmente nos países centrais, onde esse modelo de democracia tinha se consolidado. Essa crise se revela tanto na participação nos processos eleitorais, o que se vê a partir do aumento dramático do abstencionismo, quanto na confiança dos cidadãos em relação aos seus representantes.

A insatisfação das pessoas com o funcionamento das democracias atuais evidencia os limites do modelo de democracia hoje predominante nas sociedades capitalistas, que têm como consequência uma desilusão com a política partidária, uma desconfiança em relação às instituições democráticas, um descontentamento com os representantes políticos (dado o agravamento sem precedentes da crise social, o aumento da corrupção e a falta de compromisso com os ideais democráticos), assim como uma falta, por parte dos cidadãos, em participar de uma eleição em que o processo eleitoral é visto como o ponto em que se esgota a sua participação política (o ato de votar).

O processo de reabertura política da sociedade brasileira, alicerçada no anseio da população que havia saído às ruas para pedir o direito ao voto para presidente, negado durante 21 anos pelo regime militar, parece ter perdido o seu encanto diante dos últimos pleitos eleitorais. De acordo com o resultado das eleições presidenciais de 2010 a 2018, podemos verificar que a taxa de abstenção teve pequenas oscilações, permanecendo em uma proporção acima de 20\%; e os votos nulos também, nas três últimas eleições, apresentando, nas eleições de 2018, um aumento de $60 \%$.

No contexto do nosso objeto de estudo, a cidade do Natal, a taxa de abstenção aumentou 36,06\% entre as eleições de 2014 e 2018, saltando de $13,28 \%$ para $18,07 \%$ do eleitorado, considerando as mudanças no quantitativo de eleitores do mesmo período, enquanto a média brasileira cresceu menos de $1 \%(0,94 \%)^{5}$ entre 2014 e 2018.

No que diz respeito ao resultado dos votos brancos e nulos, foi possível, a partir dos dados geocodificados, usados como forma de melhor visualizar a incidência dos votos sobre as localidades e sua assimetria na distribuição espacial, chamar a atenção para a predominância dos votos brancos e nulos em territórios classificados como vulneráveis, dadas as condições sociais existentes (baixo grau de instrução e carência de equipamentos e serviços públicos). Os bairros de Mãe Luiza (21\%), Felipe Camarão e Cidade Nova (20\%) apresentaram as maiores incidências, enquanto os bairros de Tirol, Candelária e Capim Macio concentraram $10 \%$ dos votos brancos e nulos. Estes últimos possuem grupos com grau de instrução mais elevado, detendo maior acesso 
Gráfico 1 - Taxa de abstenção, votos nulos e brancos, nas eleições presidenciais brasileiras entre 2010 a 2018 - 2o turno - Brasil

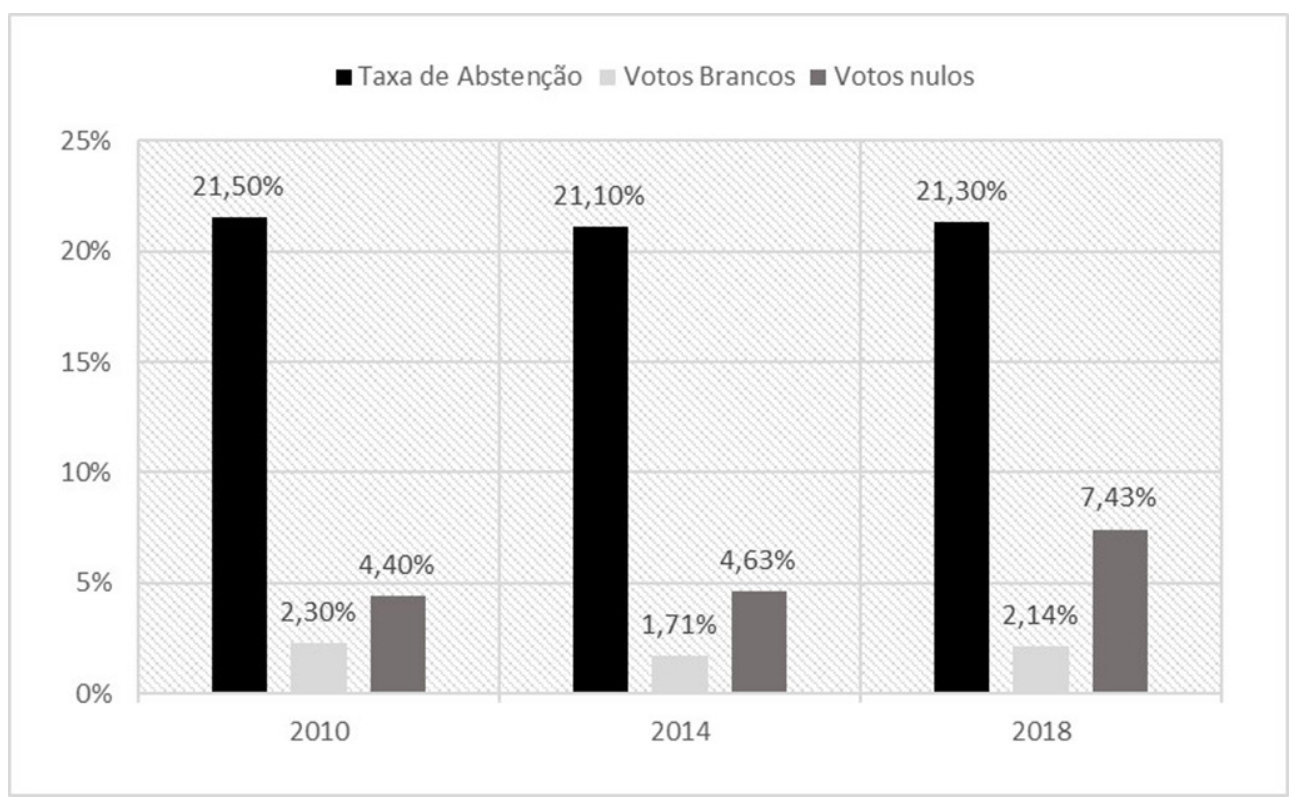

Fonte: elaborado pelos autores, com base nos dados do TSE (Brasil, 2020).

Gráfico 2 - Taxa de abstenção nas eleições presidenciais brasileiras entre 2014 e 2018 - 20 turno - Natal/RN

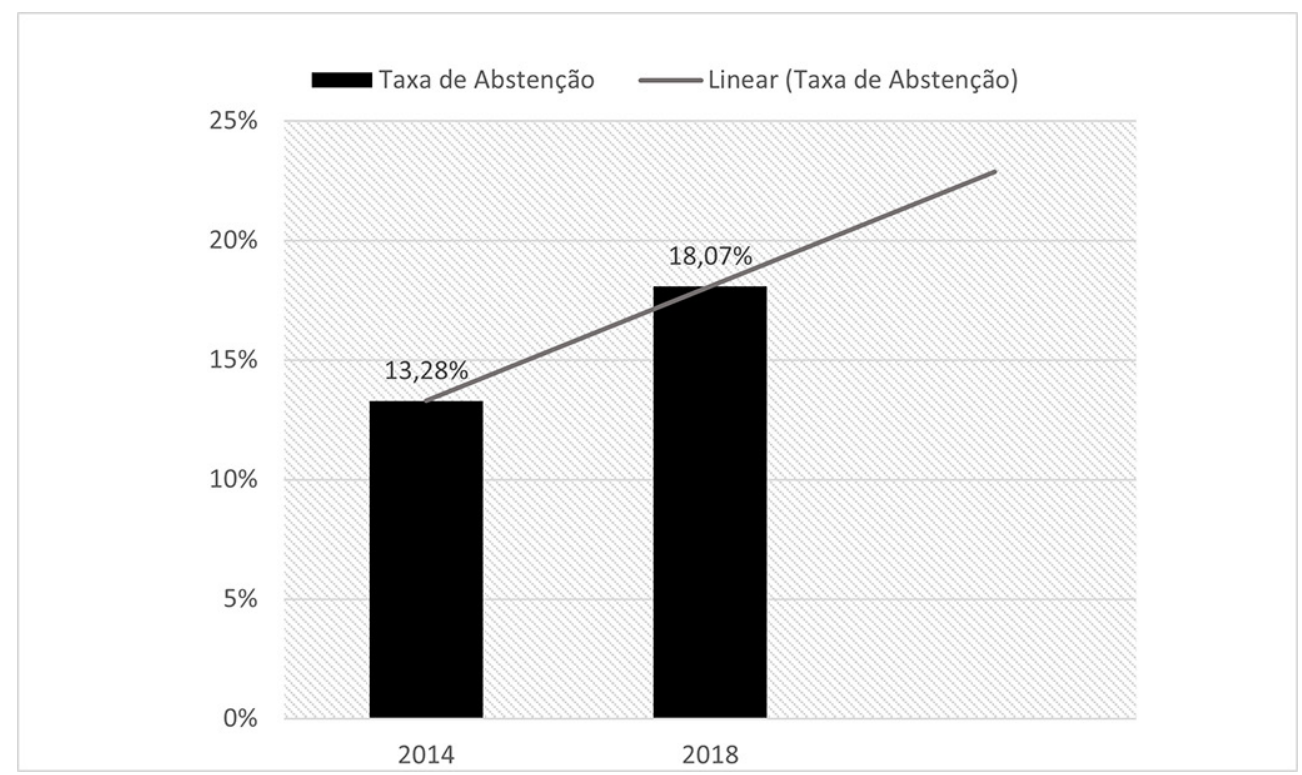

Fonte: elaborado pelos autores, com base nos dados do TSE (Brasil, 2020). 
a equipamentos e serviços públicos, o que pode nos revelar intencionalidades diferentes ao escolher entre essas opções de voto.

Conforme observamos no Mapa 1, há um número expressivo de eleitores descontentes com a democracia brasileira, o que pode ser explicado tanto pela ausência do Estado no atendimento aos direitos sociais com políticas públicas efetivas, como pelo descrédito em relação aos atores políticos envolvidos em casos de corrupção. A nossa proposta não foi adentrar profundamente em aspectos que justifiquem a escolha dos votos brancos e nulos, na esfera socioeconômica ou político-institucional. Até porque imergir sobre o interesse político e a consciência cívica da cidade mereceria uma análise mais robusta. No entanto, a constatação acima apresentada é um elemento

Mapa 1 - Distribuição espacial dos votos.

Eleições presidenciais de $2018,2^{\circ}$ turno - votos brancos e nulos

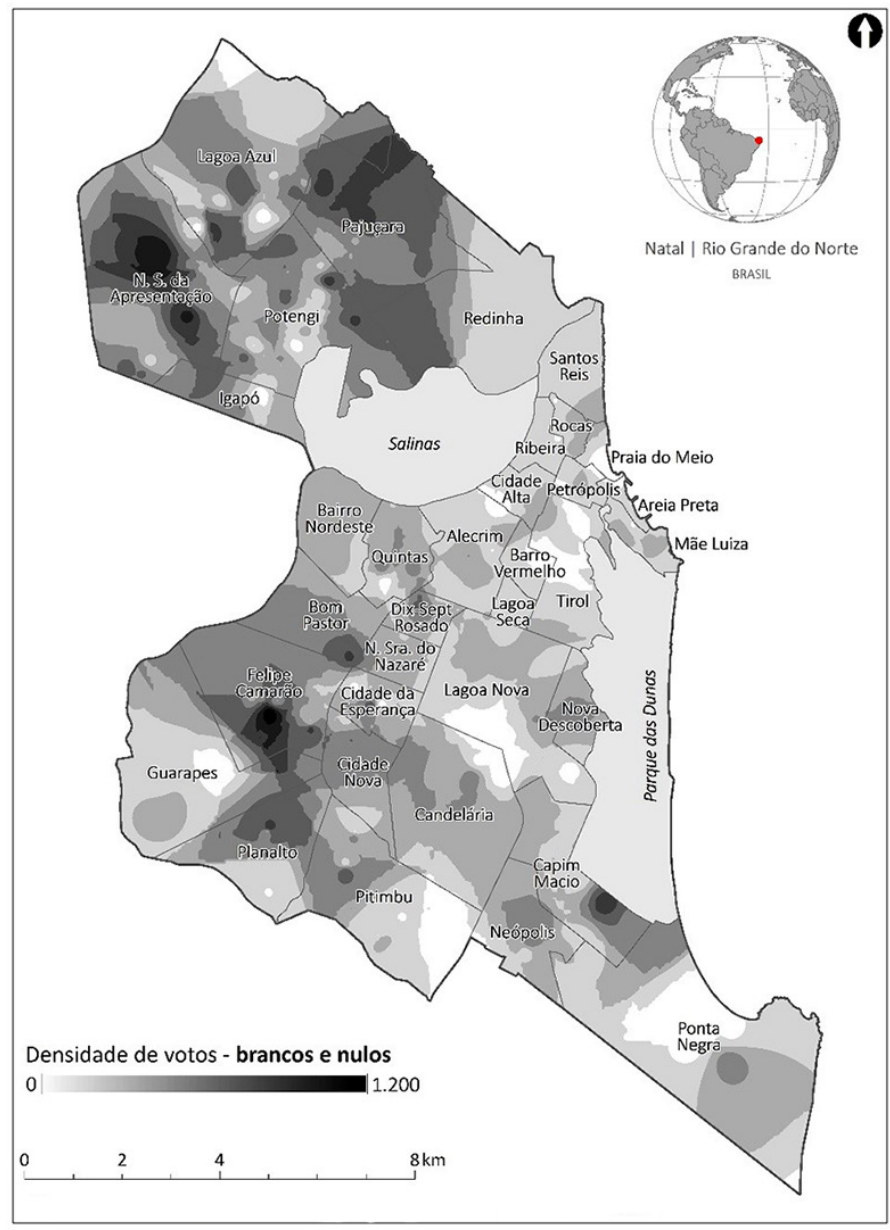

Fonte: Tribunal Regional Eleitoral de Rio Grande do Norte (TRE/RN, 2018). 
adicional para pensar que o ressentimento pode vir também na opção por esse tipo de voto, já que no Brasil o voto é obrigatório.

Um aspecto importante de ser ressaltado na política brasileira, que se repete nas eleições presidenciais de 2018, diz respeito à antiga polarização entre o PT e o PSDB, partidos que agrupavam a maior parte dos votos desde 1994, como analisam Limongi e Cortez (2010).

No cenário político do Brasil, a partir de 1994, o PT e PSDB protagonizaram embates em todas as eleições. No entanto, em 2018, o PSDB ficou de fora do segundo turno da corrida eleitoral, tornando-se um coadjuvante na principal disputa pela primeira vez em 24 anos. Um outro marco histórico do pleito eleitoral de 2018 foi a rejeição da candidatura e, posteriormente, a prisão do ex-presidente Luiz
Inácio Lula da Silva (PT), apesar de ele figurar, naquele momento, entre os primeiros lugares nas pesquisas de intenção de voto.

As eleições de 2018 assemelham-se às eleições de 1989, ao ter um dos maiores números de candidaturas à presidência dos últimos 20 anos, sendo 13 no total; as principais delas foram de: Jair Bolsonaro (PSL), Fernando Haddad (PT), Ciro Gomes (PDT), Geraldo Alckmin (PSDB) e Marina Silva (Rede).

Os candidatos mais situados ao centro do espectro político, a exemplo: Geraldo Alckmin (PSDB) e Marina Silva (Rede), que já tinham disputado eleições presidenciais, veem seus piores resultados nesse pleito, assim como a consequente redução na votação dos seus partidos. O PSDB tem a pior votação da história, desde 1994, e Marina Silva,

Gráfico 3 - Resultado das eleições presidenciais brasileiras entre 1989 e 2014 - Brasil

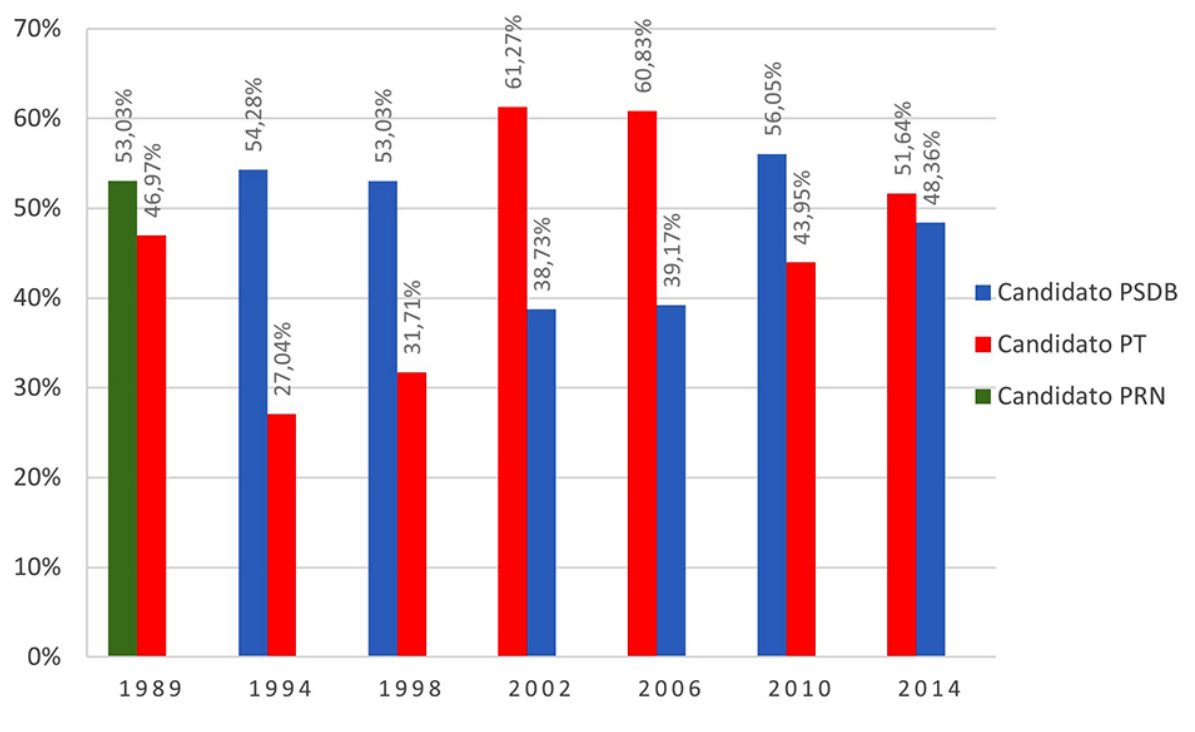


que teve mais de 20 milhões de votos em 2014, chega a pouco mais de 1 milhão de votos em 2018, evidenciando a particularidade dessa eleição no País.

O primeiro turno resumiu-se a uma disputa entre Jair Bolsonaro e Fernando Haddad, que passaram a centralizar o debate político eleitoral de 2018. Bolsonaro apresentou-se como um candidato antissistema e, ao mesmo tempo, antipetista, que canalizava sua atuação na rejeição aos governos do PT, que governaram o País por 13 anos consecutivos. Por tanto, Jair Bolsonaro levantou a bandeira anticorrupção, antissistema, colocando-se como defensor ferrenho de uma agenda liberal-conservadora que saiu vitoriosa nas eleições.

Já o principal oponente do atual presidente do Brasil, o professor Fernando Haddad, do PT, ex-prefeito de São Paulo e ex-ministro da educação dos governos Lula e Dilma, tentou atrair o eleitorado que foi beneficiado pelas políticas sociais e econômicas dos governos petistas, tentando capitanear, de último momento, os votos do ex-presidente Lula para sua candidatura. Mas, no que diz respeito aos resultados eleitorais obtidos pelo candidato, vale ressaltar que foram os piores para um candidato petista desde 2003, quando o partido chegou à Presidência da República.

Com uma força elevada nas redes sociais, a polarização política, já evidenciada anteriormente, ganha uma nova dimensão, na medida em que entra em cena um partido sem grande expressão numérica na Câmara dos Deputados, que contava com tempo de TV reduzido, direcionando toda a campanha do presidenciável Bolsonaro para as mídias digitais. 0 então candidato consegue aumentar sua popularidade, ganhando maior destaque midiático, após ser acometido por um atentado contra a sua vida, em plena corrida eleitoral, o que provocou a sua ausência nos debates eleitorais transmitidos por diversas emissoras de TV durante a campanha presidencial, assim como o consequente aumento nas intenções de voto do eleitorado. Segundo pesquisa do Ibope, ${ }^{6}$ realizada em setembro de 2018, Bolsonaro cresceu 4 pontos percentuais após o referido atentado, saindo de $22 \%$ para $26 \%$ das intenções de voto.

Um outro aspecto importante a destacar foi o apelo ao conservadorismo de parte do eleitorado a favor da candidatura de Jair Bolsonaro, o qual se colocou como um candidato símbolo de uma nova forma de fazer política, esquecendo-se da sua trajetória pública de 28 anos como parlamentar, deputado por cinco mandatos, sempre atuando na Câmara Federal naquilo que se conhece no Brasil como "baixo clero". A sua candidatura antissistema classificava-o como "uma nova liderança" no Brasil que, apesar da falta de expressão política e da ausência de uma grande coalizão partidária que o ajudasse a chegar ao poder, não inviabilizou que ele saísse vencedor no segundo turno das eleições, conquistando 55,13\% dos votos válidos, contra $44,87 \%$ do segundo colocado, vencendo em 16 estados e 21 capitais. No Nordeste, reduto primordialmente petista, logrou vitórias nas capitais do Rio Grande do Norte, Alagoas e Paraíba.

O cenário das eleições no município de Natal, vigésima cidade mais populosa do País, conta com um histórico de rivalidade política entre famílias tradicionais, que tanto possibilitou o surgimento de novas lideranças como a manutenção de antigas. No entanto, a partir da década de 1990, a cidade passou a contar com 
Gráfico 4 - Resultado das eleições presidenciais brasileiras entre 1989 e 2014 - Natal/RN

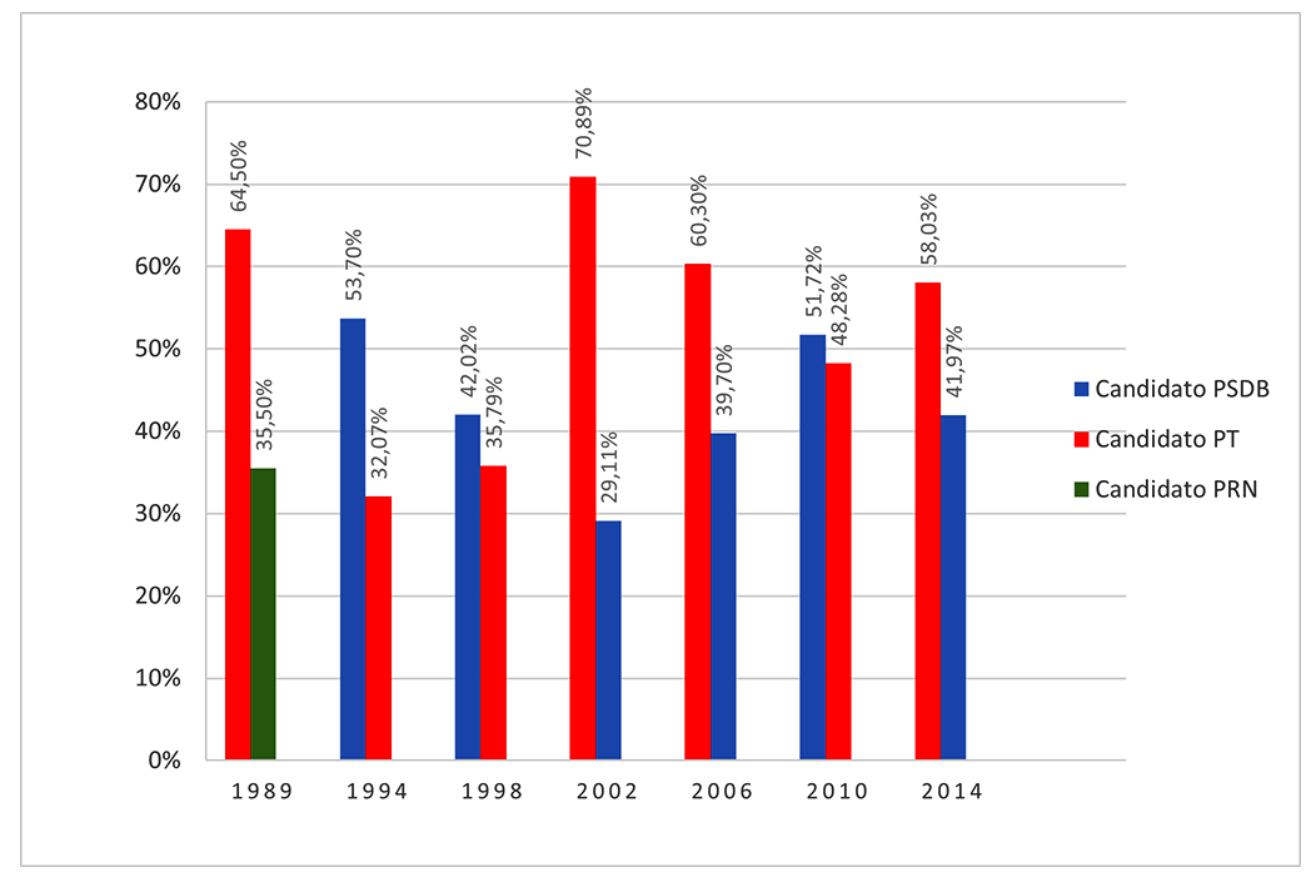

Fonte: elaborado pelos autores com base nos dados do TSE (Brasil, 2020).

uma liderança do PT na disputa para o executivo municipal, dando início a uma trajetória política no estado do Rio Grande do Norte. ${ }^{7}$

No que se refere à realização das eleições na capital, é importante destacar que Natal conta com cinco zonas eleitorais e um total de 557.715 eleitores aptos a votar (Brasil, 2020). Considerando o período de 1989 a 2014, na capital do Rio Grande do Norte, o PT obteve vitória em quatro pleitos eleitorais (1989, 2002, 2006 e 2014), demonstrando a forte influência do Governo Federal no contexto local.

Para uma compreensão das eleições 2018 em Natal, optamos inicialmente por espacializar, a partir dos 35 bairros, a votação dos candidatos presidenciais e o quantitativo de votos brancos/nulos obtidos no segundo turno das eleições; o que foi possível a partir da seleção das variáveis obtidas na base de dados do Tribunal Superior Eleitoral (TSE), apresentadas no Quadro 1. O quadro apresenta a votação de cada um dos candidatos através das medidas estatísticas de média e mediana, assim como traz a votação mínima e máxima que o candidato recebeu nos bairros da cidade. Desse modo, pode se observar que a votação média do candidato Jair Bolsonaro em Natal foi de 6.434 votos, sendo a votação mínima obtida em um bairro de 602 votos e a votação máxima de 27.371 votos. Já o candidato Fernando Haddad teve uma votação média de 5.688 votos, sendo a votação mínima obtida em um bairro de 638 votos e a votação máxima de 24.065 votos. 
Quadro 1 - Descrição das variáveis de dimensão política para Natal/RN, 2018

\begin{tabular}{|l|c|c|c|c|c|}
\hline \multicolumn{1}{|c|}{ Variável } & Média & Mediana & Desvio padrão & Mínimo & Máximo \\
\hline Votação Fernando Haddad (PT) & $5.688,31$ & $3.822,00$ & $4.923,99$ & 638 & 24.065 \\
\hline Votação Jair Bolsonaro (PSL) & $6.434,26$ & $4.429,00$ & $5.812,28$ & 602 & 2.7371 \\
\hline Votação Nulos e Brancos & $2.260,6$ & 1.604 & $2.118,581$ & 203 & 10.520 \\
\hline
\end{tabular}

Fonte: elaborado pelos autores com base em banco de dados de pesquisa autoral, em 2020.

Na disputa eleitoral de 2018, podemos chamar a atenção, a partir dos dados obtidos, para o fato de que o eleitorado de Natal optou pelo presidenciável Jair Bolsonaro desde o primeiro turno, cujos resultados para os quatro primeiros colocados foram: Jair Bolsonaro (PSL) 44,42\%; Ciro Gomes 23,57\% (PDT); Fernando Haddad (PT) 22,8\%; e Geraldo Alckmin (PSDB) $2,76 \%$.

Na disputa do segundo turno, Jair Bolsonaro teve $52,98 \%$ e Fernando Haddad $47,02 \%$ dos votos válidos totais. Como podemos ver, no mapa abaixo, os locais de votação identificados como de concentração alta dos votos têm uma ocorrência maior para o candidato Fernando Haddad nas seções existentes na 4a zona eleitoral da cidade, enquanto seu adversário conseguiu vitória nas demais zonas (1aㅡ, 2aㅡ, 3a e 69a). Dessa forma, é possível perceber os resultados divididos por zonas eleitorais: 1 a zona: Bolsonaro 51,27\% x Haddad 48,73\%; 2a zona: Bolsonaro 55,59\% x Haddad 44,41\%; 3a zona: Bolsonaro 56,79\% x Haddad 43,21; 4a zona: Haddad 50,51\% x Bolsonaro 49,49\%; e 69a zona: Bolsonaro 50,55\% x Haddad 49,55\%.
É possível perceber com base nas variáveis expressas no mapa de distribuição por superfície de tendência quais foram os resultados dos candidatos Fernando Haddad e Jair Bolsonaro na cidade. Considerando que Natal conta com 23,5\% do eleitorado do Rio Grande do Norte, ${ }^{8}$ o mapa fornece-nos uma visão aproximada da distribuição espacial dos votos. Os dados geocodificados foram separados por competidores como forma de melhor visualizar a incidência dos votos sobre as localidades e sua assimetria na distribuição espacial. Os mapas de superfície de tendência mostram a distribuição média dos votos dos candidatos Jair Bolsonaro e Fernando Haddad, e sua leitura permite identificar as características gerais do eleitorado em Natal, principalmente as parcelas do território em que há maior densidade eleitoral.

Na Região Administrativa Norte, observamos uma diferença, sobretudo no bairro Pajuçara, local onde tende a ser mais forte a escolha por Haddad. Já, na Região Administrativa Sul, sobretudo no bairro de Capim Macio, a escolha tende a ser mais forte 
pela candidatura de Bolsonaro. Além disso, é possível apontar um leve predomínio de Bolsonaro na área mais central de Natal - nos bairros Tirol, Cidade Alta e Petrópolis -, muito embora os mapas evidenciem um forte equilíbrio na disputa Fernando Haddad versus Jair Bolsonaro em toda a cidade.
Comparando os mapas anteriores, o da votação de Fernando Haddad e o da de Jair Bolsonaro, podemos verificar que o eleitor natalense decidiu pela vitória do atual presidente na maioria dos bairros. No entanto, é importante ressaltar que ocorreu uma disputa acirrada em todas as seções eleitorais, variando

Mapa 2 - Distribuição espacial dos votos.

Eleições 2018, $2^{\circ}$ turno - Fernando Haddad (PT)

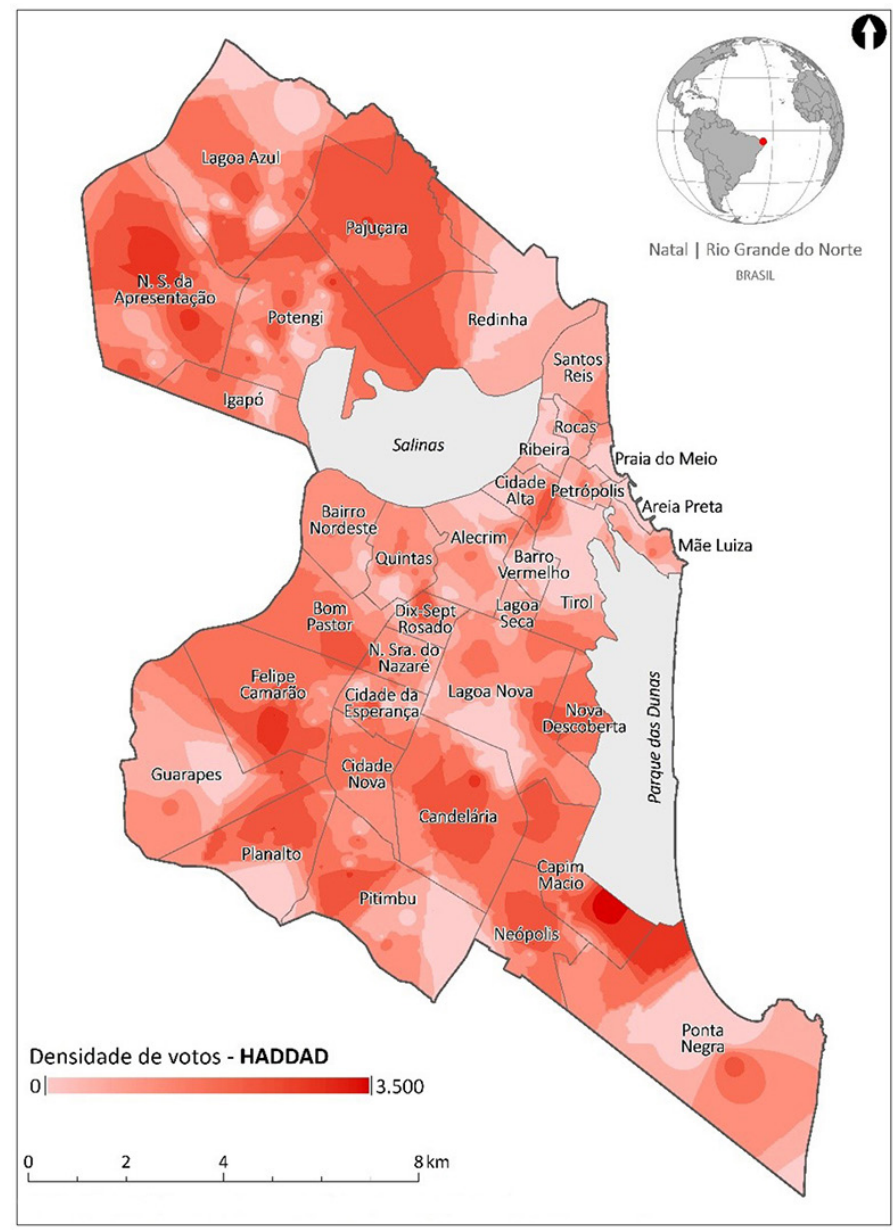

Fonte: Tribunal Regional Eleitoral de Rio Grande do Norte (TRE/RN, 2018). 
Mapa 3 - Distribuição espacial dos votos.

Eleições 2018, $2^{\circ}$ turno - Jair Bolsonaro (PSL)

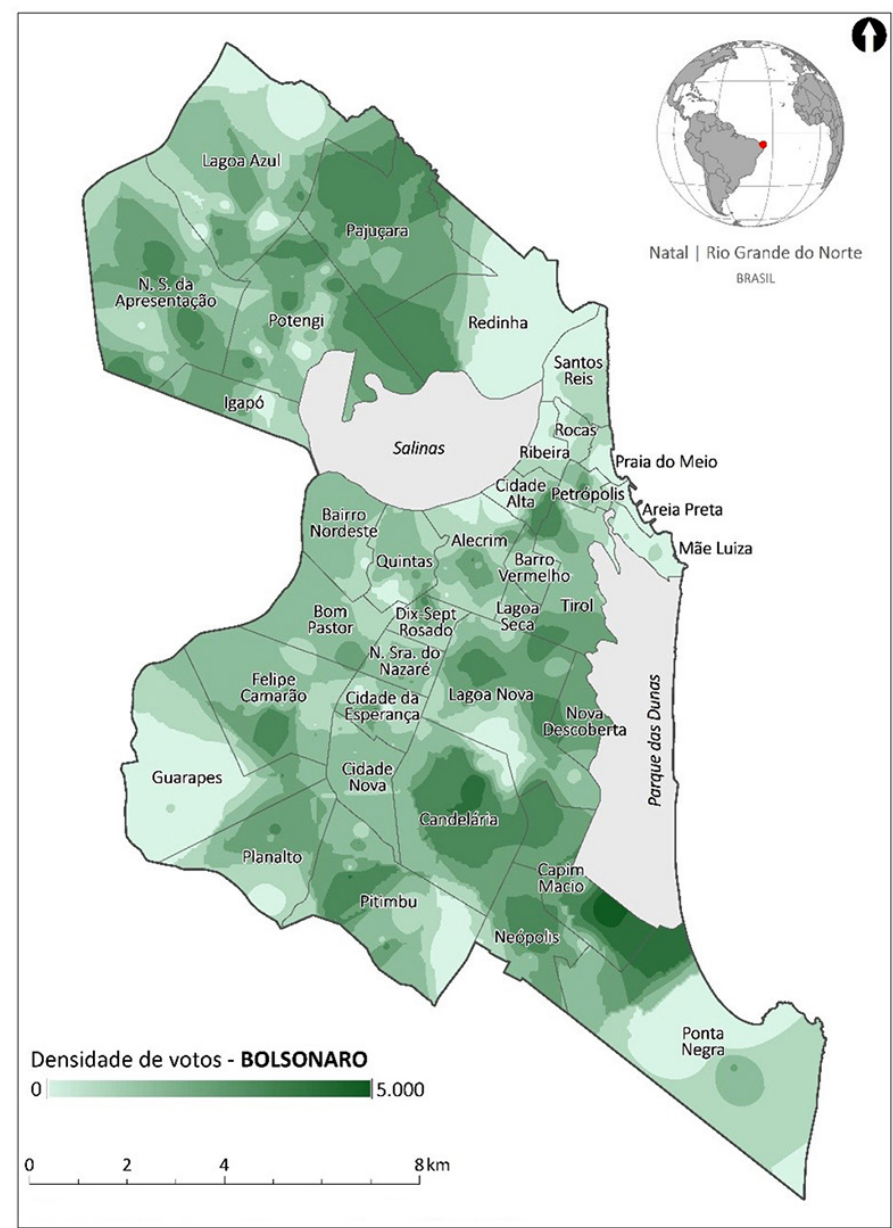

Fonte: Tribunal Regional Eleitoral de Rio Grande do Norte (TRE/RN, 2018).

de uma maioria de $1 \%$ a $5 \%$ a mais do que o segundo colocado. Dessa forma, encontramos uma forte correlação entre o grau de competitividade do voto em cada área da cidade com a distribuição das características socioeconômicas da população do município.
Em todas as áreas da cidade, o voto é equilibrado entre os dois candidatos, independentemente da área em que se localizam as elites dirigentes ou os setores mais periféricos socialmente. Uma concentração um pouco maior dos votos petistas predominou 
na 4a zona eleitoral, onde se localiza o bairro do Guarapes, um bairro periférico de Natal. Essa localização se caracteriza com a predominância de uma população de baixa renda que é carente da prestação de serviços e possui altos índices de violência urbana. A única localidade em que Fernando Haddad obteve votação superior aos $50 \%$ foi no bairro acima citado. Os dados da prefeitura referentes aos bairros da cidade evidenciam que o bairro em questão possui um rendimento nominal médio mensal de 0,53 , abaixo da média da cidade que é de 1,78 salários-mínimos. No tocante às taxas de alfabetização, o Guarapes tem, para a alfabetização de pessoas de 5 anos ou mais, o percentual de $72 \%$. Além disso, $33,47 \%$ de sua população é exposta a esgoto a céu aberto (Natal, 2016).

Mapa 4 - Proporção espacial dos votos por bairros.

Eleições 2018, $2^{\circ}$ turno - Fernando Haddad (PT)

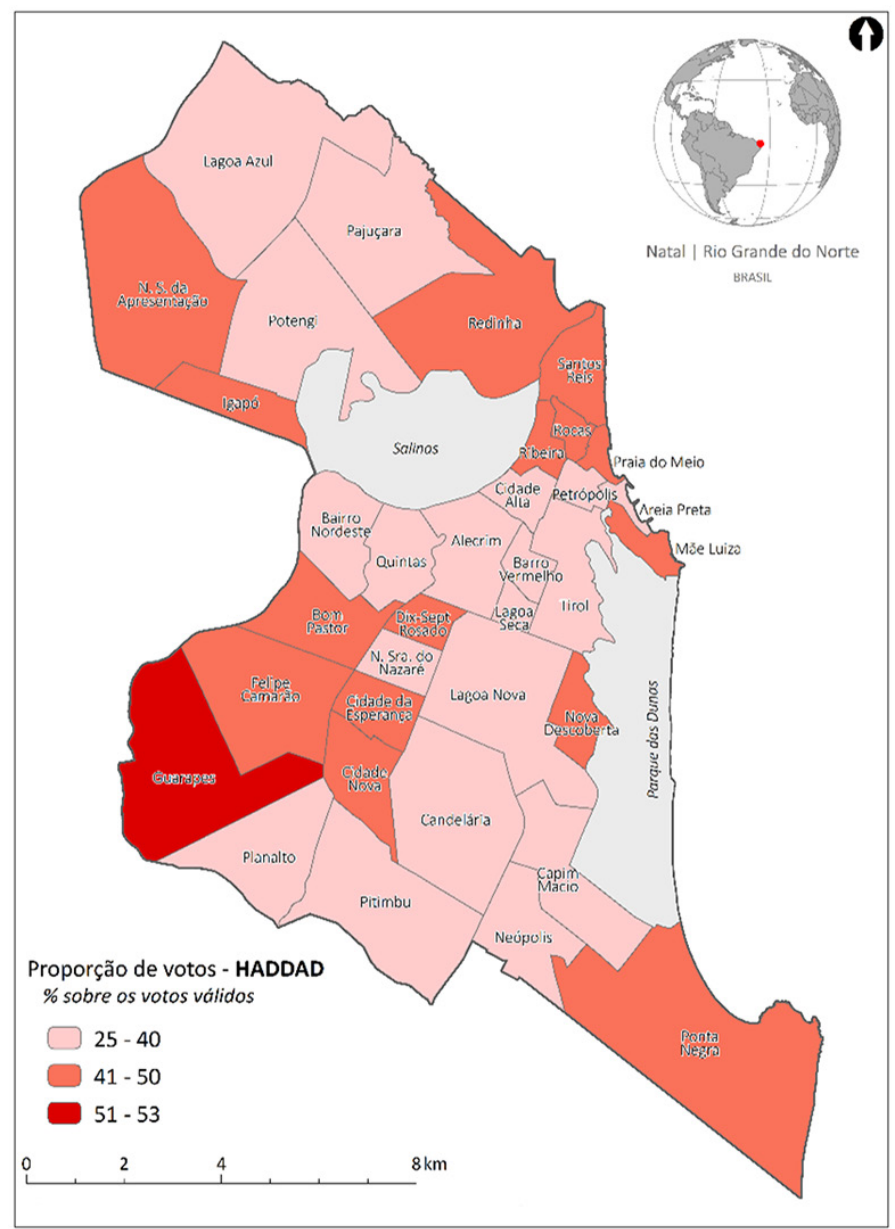

Fonte: Tribunal Regional Eleitoral de Rio Grande do Norte (TRE/RN, 2018). 
O PT também obteve votação expressiva em Mãe Luiza (49\%), Redinha e Santos Reis (47\%) e Ponta Negra (45\%). Com exceção de Ponta Negra, todos os outros bairros contam com caraterísticas também periféricas, sendo possível encontrar uma forte correlação desses resultados com as características socioeconômicas. Além disso, é importante destacar a influência dos programas sociais do governo petista, como o Programa Bolsa Família (PBF), na votação do candidato Haddad.

No que tange à votação do candidato Jair Bolsonaro, observamos que ele saiu vitorioso em 4 das 5 zonas eleitorais, perdendo apenas na 4a zona eleitoral, como citado anteriormente. Há uma concentração dos seus

Mapa 5 - Proporção espacial dos votos por bairro.

Eleições 2018, $2^{\circ}$ turno - Jair Bolsonaro (PSL)

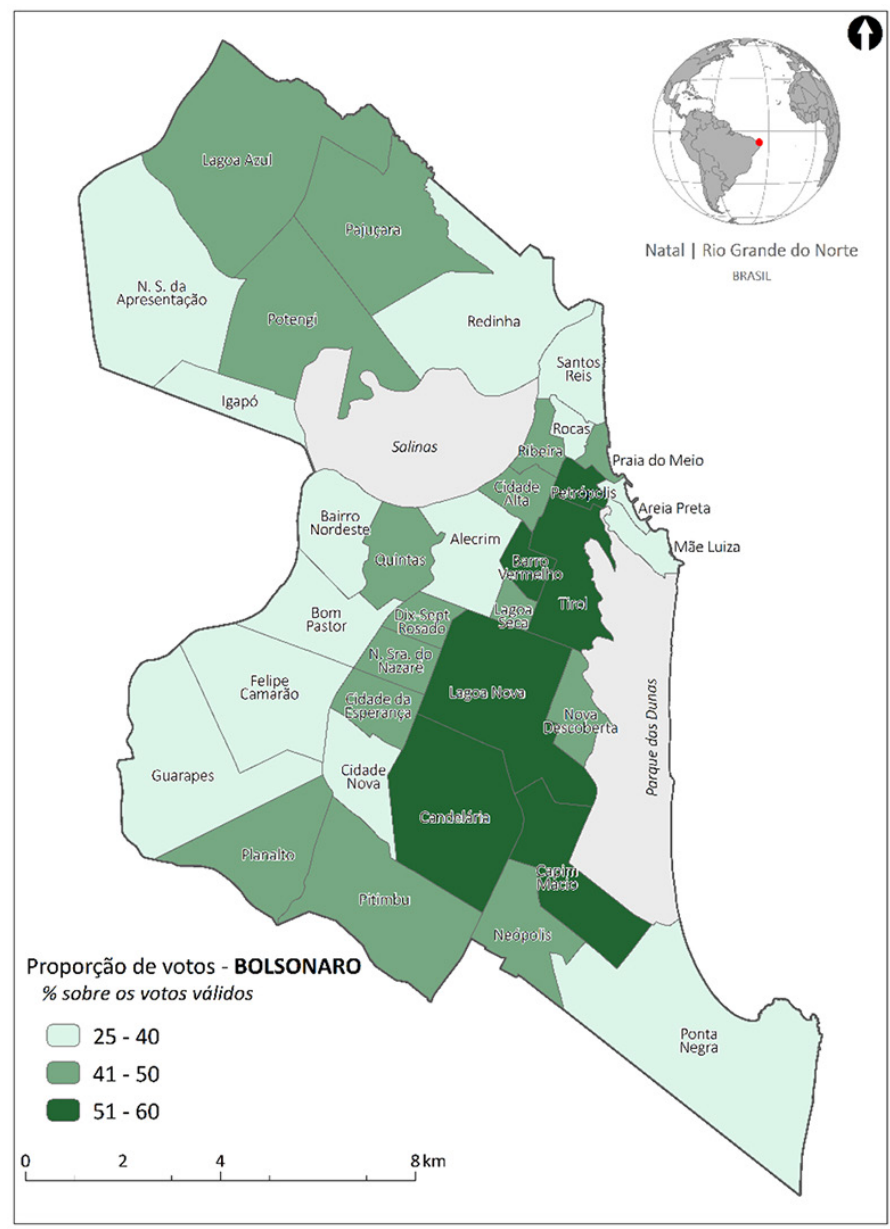

Fonte: Tribunal Regional Eleitoral de Rio Grande do Norte (TRE/RN, 2018). 
votos, principalmente, nos bairros nobres da cidade, como, por exemplo: Tirol (60\%), Barro Vermelho (57\%), Candelária (54\%), Lagoa Nova (52\%), Capim Macio (51\%), Areia Preta (51\%) e Petrópolis (51\%). Esses bairros possuem rendimento nominal médio mensal variando de 6,74 (Tirol) a 4,01 (Lagoa Nova) e todos eles têm taxa de alfabetização acima dos $96 \%$ (ibid.). Esses resultados nos revelam que os descontentes com os governos petistas também estão localizados em bairros da cidade que contam com uma população com maior grau de instrução, com rendas per capita mais altas da cidade e com maior oferta de equipamentos e serviços públicos.

Esta pesquisa se preocupou em não se tornar um acúmulo de descrições de fenômenos. A tentativa foi ir além dos dados imediatos, principalmente para algo que não estivesse diretamente observado, e, por meio do recurso de mapas, auxiliar em uma imersão espacial do fenômeno político pelos bairros da cidade. Diante desse contexto, é necessário chamar a atenção para o fato de que o eleitor ressentido não se localiza apenas nos lugares excluídos. 0 ressentimento surgiu não como uma reação pessoal apenas de todas "as pessoas que não importam", mas também daquelas que são socialmente incluídas. Podemos perceber que a votação não está concentrada apenas em contextos que vivenciaram o declínio econômico e social na cidade, resultado de um empobrecimento causado pela recessão econômica que assolou o País nos últimos anos. Mas, ao que tudo indica, o ressentimento contempla diferentes grupos sociais que se sentem mobilizados por valores e princípios éticos do setor público que foram ameaçados pela dinâmica política do País.
Um sentimento de ódio contra o legado do PT desenvolveu, de forma ainda mais radical, a polarização supracitada, dando início à criação de um fenômeno político chamado Jair Bolsonaro, "o mito". Portanto, a análise do comportamento do eleitorado natalense demonstrou que o eleitorado ressentido está distribuído em diversas localidades, não só em regiões de periferia, contemplando diferentes perfis socioeconômicos.

\section{Considerações finais}

Como as conclusões para os fenômenos políticos hoje são relativamente incertas, até porque esse universo vem mudando rapidamente nos últimos anos, as análises aqui empreendidas ajudam a compreendê-los, mesmo quando as imprecisões sobre as nossas conclusões são altas. A pretensão foi contribuir na construção de explicações científicas para o entendimento do "eleitor ressentido" (Ferrão, 2019) no contexto brasileiro, dado o protagonismo que esse tema vem ganhando em vários países do mundo. A escolha pelas últimas eleições acontece, justamente, por ser nelas que esse fenômeno ganha dimensões que vêm afetando a forma de fazer política no Brasil.

Constatamos, a partir da análise aqui desenvolvida, que a redução da participação eleitoral evidenciada no aumento das taxas de abstenção e no alto percentual de votos brancos e nulos, assim como o enfraquecimento de partidos tradicionais da política brasileira de centro-esquerda (PT) e centro-direita (PSDB), consagrou uma candidatura com discurso nacionalista e antissistema, acentuando ainda 
mais a polarização entre a esquerda e a direita no Brasil, tanto pela via do discurso político-partidário, como pela produção de uma imagem de um governo marcado por ideais que o caracterizam a partir da ótica da democracia iliberal, estruturada em um movimento de oposição ao mainstream progressista.

Soma-se a esse entendimento que a percepção dos votantes em relação aos candidatos tradicionais se desgastou a partir do momento em que os problemas cotidianos pareciam não ter soluções efetivas. Jair Bolsonaro surge como um candidato que apresentou soluções simplistas para resolvê-los, dando uma nova esperança, ou até mesmo uma ilusão, para aqueles que não estavam otimistas em relação ao futuro. Observamos aqui a ideia da "sua voz sou eu" (Mounk, 2018), imbuída no comportamento do candidato que se apresentava como uma figura totalmente avessa e distante da classe política tradicional, mas próxima do anseio popular de mudança - qualificando-se como representante moral desse desejo. Utilizando-se do lema "Brasil acima de tudo, Deus acima de todos", o candidato vendeu a sua agenda conservadora, atrelada aos interesses internacionais, na qual os brasileiros estariam em primeiro lugar. "American first", emitiu Donald Trump de maneira similar. Portanto, como um "vendedor de ilusões", Bolsonaro consagra sua vitória em um país que enfrentava um cenário de pessimismo diante da crise econômica e, principalmente, política que assolou a nação, dado os casos de corrupção envolvendo atores políticos que lideravam o Brasil.

Provavelmente teremos uma oportunidade, em pesquisas futuras, de redescobrirmos novas explicações sobre o ressentimento canalizado para os votos brancos e nulos na cidade do Natal. Na análise aqui realizada, à luz dos autores trabalhados, constatamos o aumento significativo dos votos brancos e nulos, que pode ser justificado pela insatisfação do eleitorado com os candidatos apresentados no pleito de 2018. Um caminho não trilhado pelos autores trabalhados, uma vez que, no Brasil, o voto é obrigatório.

Ao final desta pesquisa, temos a noção de que nossa contribuição pôde ser bem maior sobre o histórico das eleições de 2018 no Brasil do que necessariamente atestar todas as hipóteses já encontradas no cenário europeu. Até porque o ressentimento não teve classe, local ou grupo econômico específico como verificado em Natal. As consequências políticas recentes do País parecem acometer a todos e a todas, sendo o principal elemento no discurso do atual governo.

Portanto, concluímos que, para a existência de uma democracia consolidada no Brasil, independentemente dos candidatos e de suas ideologias político-partidárias, precisamos exigir representantes competentes e instituições estatais responsivas, pautadas por uma governança democrática capaz de assegurar os direitos sociais, políticos e civis que foram tão caros à sociedade brasileira. 


\section{[I] https://orcid.org/0000-0002-8520-3530}

Universidade Federal do Rio Grande do Norte, Centro de Ciências Humanas, Letras e Artes, Departamento de Políticas Públicas. Natal, RN/Brasil.

almeida.lindijane@gmail.com

\section{[II] https://orcid.org/0000-0002-1829-9413}

Universidade do Estado do Rio Grande do Norte, Faculdade de Filosofia e Ciências Sociais, Departamento de Ciências Sociais e Política. Mossoró, RN/Brasil.

terezinhaalbuquerque@yahoo.com.br

\section{[III] https://orcid.org/0000-0002-7239-5932}

Universidade Federal do Rio Grande do Norte, Centro de Ciências Humanas, Letras e Artes, Programa de Pós-Graduação em Estudos Urbanos e Regionais. Natal, RN/Brasil.

jaylanfmacedo@gmail.com

\section{Notas}

(1) Em 2016, o Congresso Nacional acatou a abertura do processo de impeachment contra a então presidente, Dilma Rousseff (PT), sob acusações de crime de responsabilidade fiscal. Em 12 de maio desse mesmo ano, após a aprovação da denúncia no Senado Federal, Dilma é afastada do cargo de presidente e o seu vice, Michel Temer (MDB), assume interinamente o cargo.

(2) A Operação Lava-Jato foi deflagrada pelo Ministério Público Federal (MPF) em 2014 com o intuito de investigar desvios de recursos públicos, inicialmente da estatal Petrobras, para atores e partidos políticos. As investigações atingiram figuras dos mais diversos partidos, entre elas o ex-presidente Lula (PT) e o ex-senador, e atual deputado federal, Aécio Neves (PSDB). As investigações iniciadas em âmbito federal passaram também a ser instauradas nos estados da federação, resultando na prisão de ex-governadores e ex-deputados federais, podendo ser citado, entre elas, a do ex-ministro do governo Dilma e candidato a governador do Rio Grande do Norte, em 2014, Henrique Alves (MDB).

(3) O presidente Jair Bolsonaro, no momento de elaboração do artigo, encontra-se sem partido.

(4) Dados coletados no site da Câmara dos Deputados. Disponível em: https://www.camara.leg.br/ deputados/bancada-na-posse. Data de acesso: 3 ago 2020.

(5) Os dados de oscilação nas taxas de abstenção foram calculados pelos autores com base nos dados coletados no sítio do Tribunal Superior Eleitoral (TSE).

(6) Dados da Pesquisa Ibope divulgados pelo jornal Gazeta do Povo. Disponível em: https://www. gazetadopovo.com.br/politica/republica/eleicoes-2018/efeito-facada-bolsonaro-sobe-noibope-e-melhora-ate-desempenho-no-2-turno-7c47y6qwjoaefjjj98b34vgge/. Data de acesso: 2 ago 2020. 
(7) Fátima Bezerra surge como a liderança principal do PT na cidade. Foi deputada federal (20032015), senadora (2015-2018) e eleita governadora do Rio Grande do Norte em 2018.

(8) Dados calculados pelos autores com base nas estatísticas do Tribunal Regional Eleitoral do RN (TRE/RN).

\section{Referências}

ALMEIDA, L. et al. (2018). Os movimentos sociais urbanos em Natal/RN: uma análise sobre a Primavera de junho na Cidade do Sol. Revista de Geografia e Ordenamento do Território, n. 13. Centro de Estudos de Geografia e Ordenamento do Território, pp. 7-32, dx.doi.org/10.17127/ got/2018.13.001.

AVRITZER, L. (2016). Impasses da democracia no Brasil. Rio de Janeiro, Civilização Brasileira.

BRASIL (2019). Bancada na posse. Câmara dos Deputados. Disponível em: https://www.camara.leg.br/ deputados/bancada-na-posse. Data de acesso: 3 ago 2020.

(2020). Repositório de Dados Eleitorais do TSE. Disponível em: http://www.tse.jus.br/eleicoes/ estatisticas/repositorio-de-dados-eleitorais-1/repositorio-de-dados-eleitorais. Data de acesso: 8 ago 2020.

CASTELLS, M. (2018). Ruptura: a crise da democracia liberal. Rio de Janeiro, Zahar.

DAHL, R. (1996). “A Democracia Poliárquica”. In: DAHL, R. Prefácio à teoria democrática. Rio de Janeiro, Zahar.

DATAFOLHA (2018). Desejo de mudança e rejeição ao PT alavancam candidatura de Bolsonaro. Disponível em: http://datafolha.folha.uol.com.br/eleicoes/2018/10/1983550-desejo-demudanca-e-rejeicao-ao-pt-alavancam-candidatura-de-bolsonaro.shtml. Acesso em: 28 jul 2020.

FERNANDES, A. S. A.; TEIXEIRA, M. A. C.; DA SILVA PALMEIRA, J. (2020). A longa conjuntura crítica brasileira desde 2013: crise e castigo. Cadernos Gestão Pública e Cidadania, v. 25, n. 81.

FERRÃO, J. (2019). "Para uma geografia com todos os lugares: reflexões a partir do caso europeu". In: FERREIRA, A.; RUA, J.; MATTOS, R. C. de. Produção do espaço: emancipação social, o comum e a "verdadeira democracia. Rio de Janeiro, Consequência.

IBGE (2010). Censo 2010. Disponível em: https://censo2010.ibge.gov.br/. Acesso em: 7 jul 2020.

(2019). Natal. Disponível em: https://cidades.ibge.gov.br/brasil/rn/natal/panorama. Acesso em: 7 jul 2020.

IBOPE (2018). Notícias e Pesquisas. Disponível em: https://www.ibopeinteligencia.com/noticias-epesquisas/?tema=13\&ano=2018. Acesso em: 28 jul 2020.

KAPLAN, R. D. (2009). The revenge of geography. Foreign Policy, n. 172, pp. 96-105.

LIMONGI, F.; CORTEZ, R. (2010). As eleições de 2010 e o quadro partidário. Novos estudos CEBRAP, n. 88, pp. 21-37. Disponível em: https://www.scielo.br/scielo.php?pid=S010133002010000300002\&script=sci_arttext. Acesso de: 8 jul 2020.

MAINWARING, S.; BRINKS, D.; PÉREZ-LIÑÁN, A. (2001). Classificando Regimes Políticos na América Latina. Dados, v. 44, n. 4, pp. 645-687. 
MARICATO, E. et al. (2013). Cidades Rebeldes: Passe livre e as manifestações que tomaram as ruas do Brasil. São Paulo, Boitempo e Carta Maior.

MOUNK, Y. (2018). The people vs. democracy: why our freedom is in danger and how to save it. Cambridge, Harvard University Press.

MOVIMENTO PASSE LIVRE (2013). "Não começou em Salvador, não vai terminar em São Paulo". In: MARICATO, E. et al. Cidades Rebeldes: Passe livre e as manifestações que tomaram as ruas do Brasil. São Paulo, Boitempo e Carta Maior.

NATAL (2016). Anuário de Natal 2016. Disponível em: https://www.natal.rn.gov.br/bvn/publicacoes/ anuario_2016.pdf. Acesso em: 18 jul 2020.

(2017). Conheça Melhor seu Bairro (Região Administrativa Sul). Disponível em: https://natal. rn.gov.br/semurb/planodiretor/anexos/estudos/CONHE\%C3\%87A\%20MELHOR\%20SEU\%20 BAIRRO\%20-\%20ZONA\%20SUL.pdf. Acesso em: 18 jul 2020.

(2017). Conheça Melhor seu Bairro (Região Administrativa Leste). Disponível em:https://natal. rn.gov.br/semurb/planodiretor/anexos/estudos/CONHE\%C3\%87A\%20MELHOR\%20SEU\%20 BAIRRO\%20-\%20ZONA\%20LESTE.pdf. Acesso em: 18 jul 2020.

(2017). Conheça Melhor seu Bairro (Região Administrativa Norte). Disponível em:https://natal. rn.gov.br/semurb/planodiretor/anexos/estudos/CONHE\%C3\%87A\%20MELHOR\%20SEU\%20 BAIRRO\%20-\%20ZONA\%20NORTE.pdf. Acesso em: 19 jul 2020.

(2017). Conheça Melhor seu Bairro (Região Administrativa Oeste). Disponível em:https://natal. rn.gov.br/semurb/planodiretor/anexos/estudos/CONHE\%C3\%87A\%20MELHOR\%20SEU\%20 BAIRRO\%20-\%20ZONA\%20OESTE.pdf. Acesso em: 19 jul 2020.

PRZEWORSKI, A. (1999). Minimalist conception of democracy: a defense. Democracy's value, v. 23, pp. $12-17$.

RODRÍGUEZ-POSE, A. (2018). The revenge of the places that don't matter (and what to do about it). Cambridge journal of regions, economy and society, v. 11, n. 1, pp. 189-209.

ROLNIK, R. (2013). "As vozes das ruas: as revoltas de junho e suas interpretações". In: MARICATO, E. et al. Cidades rebeldes: Passe Livre e as manifestações que tomaram as ruas do Brasil. São Paulo, Boitempo e Carta Maior.

SILVA, A. dos S.; CARVALHO NETO, A. (2012). Uma contribuição ao estudo da liderança sob a ótica weberiana de dominação carismática. RAM. Revista de Administração Mackenzie, v. 13, n. 6, p. 20-47.

SCHUMPETER, J. A. (1942). Capitalism, socialism and democracy. Nova York, Harper \& Row.

VAINER, C. (2013). "Quando a cidade vai às ruas". In: MARICATO, E. et al. Cidades rebeldes: Passe Livre e as manifestações que tomaram as ruas do Brasil. São Paulo, Boitempo e Carta Maior.

WEFFORT, F. C. (2003). O populismo na política brasileira. Rio de Janeiro, Paz e Terra.

ZAKARIA, F. (1997). The rise of illiberal democracy. Foreign Affairs, v. 76, pp. 21-22.

Texto recebido em 30/ago/2020

Texto aprovado em 15/out/2020 